\title{
A NEW SPECIES OF RAMUSELLA HAMMER, 1962 (ACARI, OPPIIDAE), FROM FARS PROVINCE, IRAN
}

\author{
M. A. Akrami ${ }^{1}$ L. S. Subías ${ }^{2}$ \& M. Behmanesh ${ }^{1}$
}

\section{SUMMARY}

M. A. Akrami, L. S. Subías \& M. Behmanesh. 2011. A new species of Ramusella Hammer, 1962 (Acari, Oppiidae), from Fars province, Iran. Grael/sia, 67(2): 199-203.

A new species of oribatid mite of the family Oppiidae, Ramusella (Insculptoppia) farsi sp. nov., is described from Fars province, southern Iran. The new species is characterized by the fusiform sensillus, with ten long ciliae on its head; smooth notogastral setae, presence of seta $C_{2}$, and four pairs of genital setae.

Key words: Oribatida; Oppiidae; Ramusella (Insculptoppia); new species; Fars province; Iran.

\section{RESUMEN}

M. A. Akrami, L. S. Subías \& M. Behmanesh. 2011. Nueva especie de Ramusella Hammer, 1962 (Acari, Oppiidae), de la provincia de Fars, Irán. Graellsia, 67(2): 199-203 (in English).

Se describe una nueva especie de ácaro oribátido de la familia Oppiidae, Ramusella (Insculptoppia) farsi sp. nov., procedente de la provincia de Fars, sur de Irán. La nueva especie se caracteriza por el sensilo fusiforme con 10 largos cilios en su cabeza, setas notogastrales delgadas, presencia de seta $c_{2}$ y cuatro pares de setas genitales.

Palabras clave: Oribatida; Oppiidae; Ramusella (Insculptoppia); nueva especie; provincia de Fars; Irán.

\section{Introduction}

Fars province, southern Iran, covers a land area of about $125,000 \mathrm{~km}^{2}$ (7.6\% of total area of Iran) and is located between latitudes $27^{\circ}-31^{\circ} \mathrm{N}$ and longitudes $50^{\circ}-55^{\circ} \mathrm{E}$. The elevational range in this province extends from about $450 \mathrm{~m}$ in the southern part to $4050 \mathrm{~m}$ in the northern part, with a mean of $1491 \mathrm{~m}$ a.s.1. The mean annual precipitation ranges from 150 to $1200 \mathrm{~mm}$. Fars is one of the few totally unknown provinces in Iran in relation to the taxonomic study of oribatid mite fauna. In the course of a preliminary faunistic survey of oribatid mites in this province, a number of oppiid mites (family

1 Department of Plant Protection, College of Agriculture, Shiraz University, Shiraz, Iran; E-mail: akrami@shirazu.ac.ir; mb behmanesh@yahoo.com

2 Departamento de Zoología, Facultad de Biología, Universidad Complutense, Ciudad Universitaria, 28040 Madrid, Spain; Email: subias@bio.ucm.es 
Oppiidae) were collected. Here, we describe one new species belonging to the subgenus of Ramusella (Insculptoppia).

According to Subías (2004, online version 2011), this subgenus has been represented until now by 33 species and prior to this study there were only three records of this subgenus from Iran. Bayartogtokh \& Akrami (2000) described Ramusella abarkouhiensis from central Iran (Yazd province). In his catalogue, Subías (2004) synonymized this species and Ramusella (I.) elliptica (Berlese, 1908), due to the shape of the rostral setae. Akrami \& Subías (2007) reported Ramusella (I.) insculpta (Paoli, 1908) and in 2008, described Ramusella (I.) iranica from northern Iran (Mazandaran province). The fourth Iranian species of this subgenus is presented in this paper.

\section{Material and methods}

During the course of a faunistic survey of oribatid mites in Fars province over 2009-2010, soil and litter samples were taken from the surface to a soil depth of $10 \mathrm{~cm}$ under fruit and forest trees, crop and ornamental plants and weeds. Mites were extracted from soil samples using Berlese-Tullgren funnels fixing in $75 \%$ ethanol, cleared in lactophenol and mounted in Hoyer's medium on glass microscopic slides. The slides were placed in an oven at $45^{\circ} \mathrm{C}$ for one week and then the specimens were examined using a light microscope (Zeiss Standard 20). Figures were made by using a drawing tube attached to the microscope.

\section{Results}

\section{Family Oppiidae Sellnick, 1937}

Ramusella (Insculptoppia) farsi sp. nov. (figs. 1-5)

Material eXAmined. Four adults. Holotype: Sepidan, Fars province, soil, $2^{\circ} 97^{\prime} \mathrm{N}, 52^{\circ} 40^{\prime} \mathrm{E}, 1606$ m.a.s.l., 24-VII-2009, M. A. Akrami leg. Three paratypes, one specimen: same data as holotype; two specimens: Badjgah village, Shiraz, Fars province, soil of poplar trees (Populus sp.), $29^{\circ} 32^{\prime} \mathrm{N}, 52^{\circ} 35^{\prime} \mathrm{E}$, 1810 m.a.s.1., 6-IIX-2009, M. Behmanesh leg.

TyPE DEPOSITORY. The specimens are deposited in the Acarological Collection, Department of Plant Protection, College of Agriculture, Shiraz University, Shiraz, Iran.

DiAGNOSIS. The new species is characterized by the fusiform sensillus, with ten long barbs on its head; smooth notogastral setae; seta $c_{2}$ developed; four pairs of genital setae present.

DESCRIPTION. Measurements: Holotype: body length $259 \mu \mathrm{m}$, width of notogaster $111 \mu \mathrm{m}$; paratypes $(n=3)$ : body length $199-240 \mu$ m (mean 213), width of notogaster 102-104 $\mu \mathrm{m}$ (mean 103).

Prodorsum (figs. 1-2). Rostrum rounded at tip; rostral setae (ro) long, arched, inserted far to each other on the dorsolateral sides of the rostrum, slightly longer than their mutual distance, with fine ciliae unilaterally; lamellar setae (le) short, about half as long as ro, finely ciliate; interlamellar setae (in) short, as long as lamellar setae, glabrous; exobothridial setae (ex) also short and glabrous, slightly longer than in; sensillus ( $s s$ ) long, fusiform, its head with ten long barbs unilaterally; bothridia round, with wide opening; three pairs of muscle sigillae situated between the interlamellar setae in two longitudinal rows, two sigillae between each interlamellar seta and bothridium, and some sigillae anterior to each bothridium; lamellar and translamellar lines well developed.

Notogaster (fig. 1). Notogaster elongate oval and narrow, rounded in both anterior and posterior directions, dorsosejugal suture convex; nine pairs of notogastral setae long and glabrous, seta $c$, very short, weakly developed, the rest of setae almost equal in length, seta la situated more posterior to $\mathrm{Im}$; Lyrifissure im and latero-opisthosomal gland ( gla) opening well developed.

Epimeral region (fig. 3). With a few muscle sigillae; apodemes $I, I I, S j$ and $I V$ well developed; epimeral setal formula (I-IV) 3-1-3-3; epimeral setae mostly short, thin and smooth, only $3 c$ and $4 c$ finely barbed.

Anogenital region (fig. 3). Genitoanal plates with four pairs of genital $\left(g_{1}-g_{4}\right)$ (two arranged on anterior half and other two on posterior half the plates), one pair of aggenital (ag), two pairs of anal $\left(a n_{1}-a n_{2}\right)$ and three pairs of adanal setae $\left(a d_{1}-a d_{3}\right)$, $a d_{3}$ situated in preanal position near $a g$, all anogenital setae smooth; ano-genital region smooth with few small sigillae situated posterolaterad of each epimeral setae $4 b$; iad fissures in adanal position and adjacent to anal plates.

Legs (figs. 4-5). Leg setation normal for the family, all tarsi monodactylous. Formula of leg setation including famulus (trochanter to tarsus): I (1-5-2-4-20); IV (1-2-2-3-10) and the formula of solenidia: I (1-2-2); IV (0-1-0). On tarsus I solenidia $\omega_{1}$ and $\omega_{2}$ nearly equal in length; famulus $\varepsilon$ 

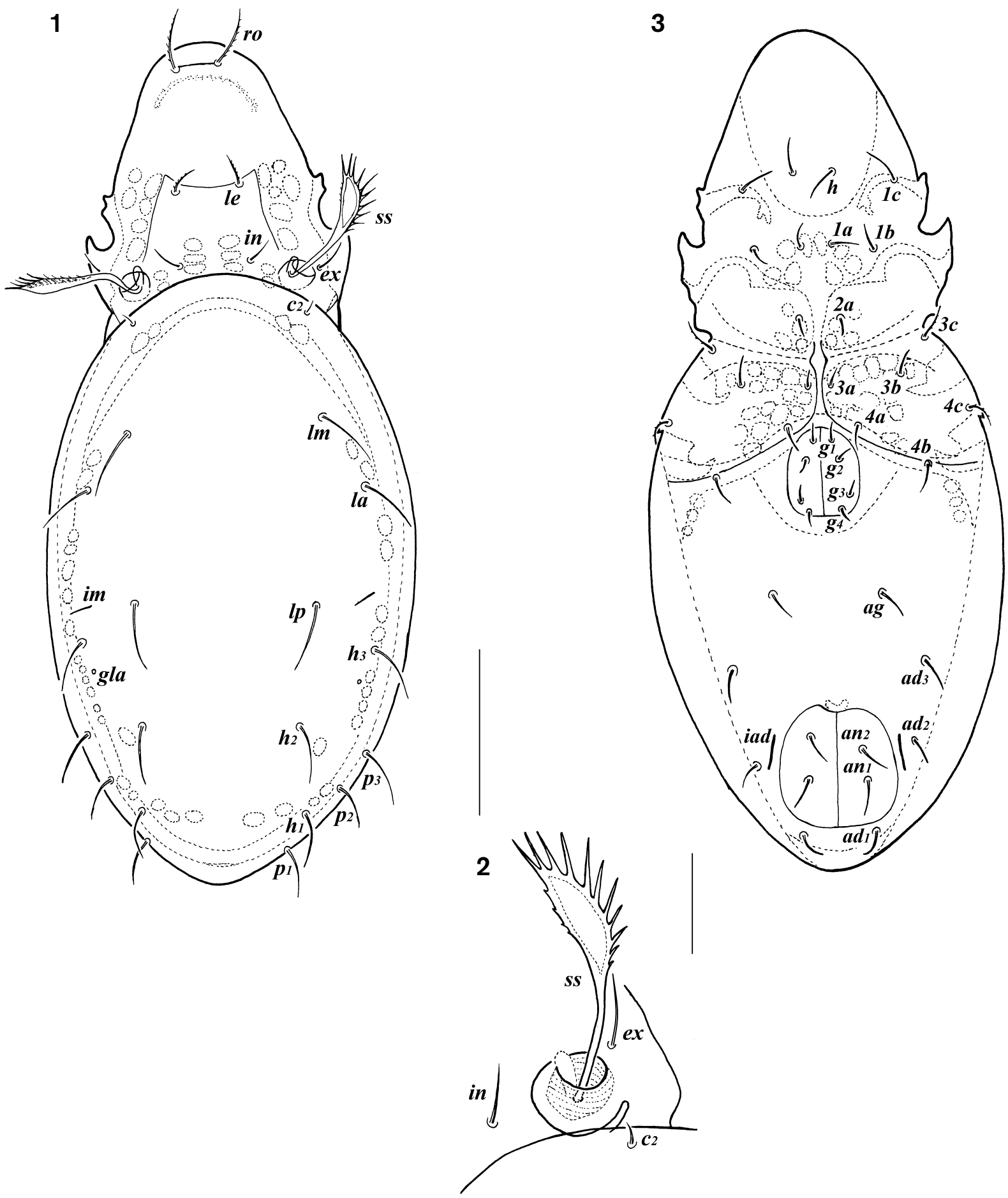

Figs. 1-3.- Ramusella (Insculptoppia) farsi sp. nov. 1) Dorsal view and 3) ventral view of holotype (scale bar 50 um). 2) Sensillus of holotype (scale bar $15 \mu \mathrm{m}$ ).

Figs. 1-3.- Ramusella (Insculptoppia) farsi sp. nov. 1) Vistas dorsal y 3) ventral del holotipo (escala 50 m). 2) Sensilo del holotipo (escala $15 \mu \mathrm{m})$. 

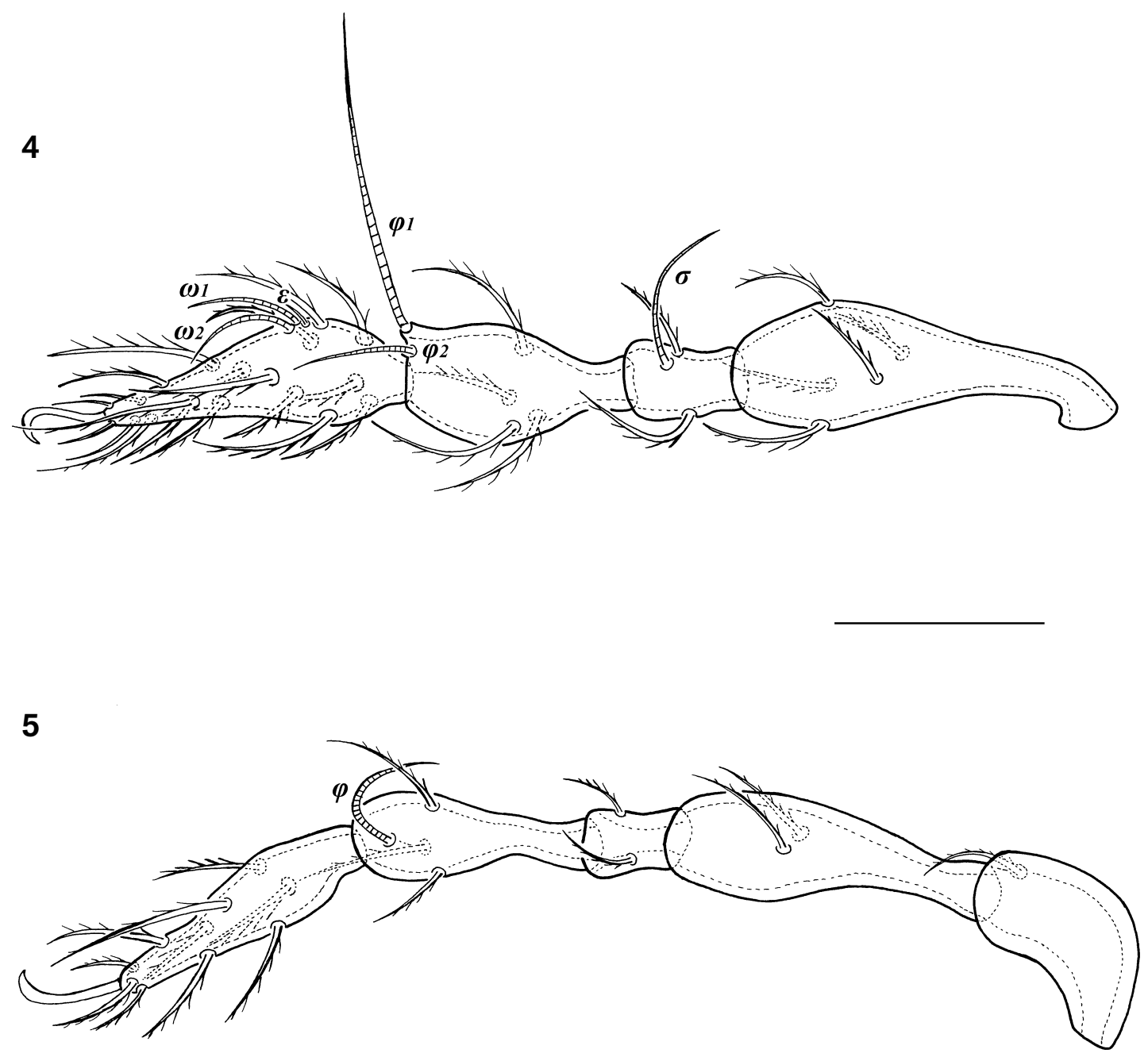

Figs. 4-5.- Ramusella (Insculptoppia) farsi sp. nov. 4) Leg I of holotype. 5) Leg IV of holotype. Scale bar $25 \mu \mathrm{m}$.

Figs. 4-5.- Ramusella (Insculptoppia) farsi sp. nov. 4) Pata I del holotipo. 5) Pata IV del holotipo. Escala 25 m.

short and slender, situated behind $\omega_{l}$, tibia I with extremely long solenidion $\varphi_{1}$ and short $\varphi_{2}, \varphi_{2}$ just under half length of $\varphi_{1}$; genu I with solenidion $\sigma$ slightly longer than $\omega$ and $\varphi_{2}$; also tibia IV with solenidion $\varphi$ about same length as dorsolateral setae.

EтYMology. The specific name "farsi" refers to the region of the type locality of this species, Fars province of Iran.

REMARKS. The new species resembles the Turkish species, Ramusella (Insculptoppia) luxtoni (Ayyildiz, 1989) in the shape of the sensillus, by having four pairs of genital setae and approximately equal body length $(250-280 \mu \mathrm{m}$ in Ramusella (I.) luxtoni), but this species differs from the new species by the absence of setae $c_{2}$, shorter sensilli, and same transverse level of setae $l a(=t e)$ and $l m$ $(=t i)$. In the shape of sensillus, the presence of short, but well developed setae $c_{2}$, and anterior location of setae $l m$ close to la, Ramusella (I.) farsi sp. nov. is also similar to Ramusella (I.) elmela Subías \& Rodríguez, 1986 (= Oppia sp. Hammer, 1977) from Pakistan, but the latter is distinguishable from the new species by having five pairs of genital setae, and barbulated notogastral, anal and 
adanal setae. The Iranian species, Ramusella (I.) iranica, has the notogastral setae $c_{2}$ similarly to the new species, but the former species differs in having five pairs of genital setae, barbulated notogastral and adanal setae, far larger body size (390-445 $\mu \mathrm{m}$ in length, $155-180 \mu \mathrm{m}$ in width), and sensilli only with six barbs.

\section{Acknowledgements}

This study was partly supported by the project "Fauna of oribatid mites of Shiraz, Fars province" funded by Shiraz University.

\section{References}

Akrami, M. A. \& Subías, L. S., 2007. Oppiid mites (Acari: Oribatida: Oppiidae) from Mazandaran province (Northern Iran), with a description of Medioppia bipectinata sp. n. Systematic \& Applied Acarology, 12: 237-243.

Akrami, M. A. \& Subías, L. S., 2008. Two new species of the subfamily Multioppiinae Balogh, 1983 (Acari: Oribatida: Oppiidae) from Iran. Journal of the Acarological Society of Japan, 17(2): 93-99.

Ayyildiz, N., 1989. Mites of the family Oppiidae (Acari: Oribatida) from Turkey. Journal of Natural History, 23: 1373-1379. doi: 10.1080/00222938900770741

Bayartogtokh, B. \& Akrami, M. A., 2000. Oribatid mites (Acari: Oribatida) from Iran, with description of two new species. Journal of the Acarological Society of Japan, 9(2): 129-145. doi: 10.2300/acari.9.129

Hammer, M., 1977. Investigatinons on the oribatid fauna of North-West Pakistan. Det Kongelige Danske Videnskabernes Selskab Biologiske Skrifter, 21(4): 1-67.
Subías, L. S., 2004. Listado sistemático, sinonímico y biogeográfico de los ácaros oribátidos (Acariformes: Oribatida) del mundo (excepto fósiles). Graellsia, 60 (número extraordinario): 3-305. doi:10.3989/graellsia. 2004.v60.iExtra. Online version accessed in February 2011. 561 pp.; http://www.ucm.es/info/zoo/Artropodos/ Catalogo.pdf.

Subías, L. S. \& Rodríguez, P., 1986. Oppiidae (Acari: Oribatida) de los sabinares (Juniperus thurifera) de España, II. Ramusella (Insculptoppia) Subías y Ramuselloppia n. gen. Boletín de la Asociación Española de Entomología, 10: 83-94. 